\title{
PEMILIHAN SUPPLIER BIJI PLASTIK DENGAN METODE ANALITYCAL HIERARCHY PROCESS (AHP) DAN TECHNIQUE FOR ORDER PREFERENCE BY SIMILARITY TO IDEAL SOLUTION (TOPSIS)
}

\author{
Jeehad Muhammad ${ }^{1}$, Diah Rahmanasari ${ }^{1}$, Joshua Vicky ${ }^{1}$, Wahyu Ani Maulidiyah', Wahyudi \\ Sutopo ${ }^{2^{*}}$, Yuniaristanto ${ }^{2}$ \\ 1)Program Studi Teknik Industri, Fakultas Teknik, Universitas Sebelas Maret \\ 2)Riset Grup Teknik Industri dan Techno-Economy, Program Studi Teknik Industri, Fakultas Teknik, \\ Universitas Sebelas Maret \\ Email: syafiqurbayani@student.uns.ac.id; diahhrahma@student.uns.ac.id; \\ joshuaivychen@student.uns.ac.id; Wahyuani_ms@student.uns.ac.id; wahyudisutopo@staff.uns.ac.id; \\ yuniaristanto@ft.uns.ac.id
}

Artikel masuk : 20-07-2020

Artikel direvisi : 09-09-2020
${ }^{*}$ Penulis Korespondensi

Artikel diterima : 10-10-2020

\begin{abstract}
Abstrak -- Perusahaan perlu mengevaluasi kinerja supplier untuk mendapatkan supplier masuk sesuai dengan kriteria perusahaan. Permasalahan pada PT. Wonorejo Makmur Abadi adalah belum adanya kriteria dan standar yang tepat untuk ditetapkan dalam pemilihan supplier sehingga perusahaan tidak adanya evaluasi kinerja supplier. Tujuan dari penelitian ini adalah untuk mengetahui bobot nilai dari setiap kriteria yang digunakan dalam pengambilan keputusan pemilihan alternatif supplier terbaik di PT "Wonorejo Makmur Abadi". Kriteria yang digunakan ada tujuh, antara lain: Harga pembelian, kualitas, waktu tenggang pembayaran, ketepatan pengiriman, kemampuan pemenuhan terhadap jumlah pemesanan, jarak supplier, dan pelayanan. Untuk mendapatkan data yang lengkap, peneliti menggunakan metode berupa wawancara dan pengisian kuesioner. Metode yang digunakan dalam pengolahan data pada penelitian ini yaitu metode AHP dan TOPSIS. Berdasarkan pengolahan data menggunakan metode AHP dihasilkan bobot dengan kriteria tertinggi yaitu pada harga pembelian, dilanjutkan secara berturut-turut yaitu kriteria kualitas, waktu tenggang pembayar, ketepatan pengiriman, kemampuan pemenuhan terhadap jumlah pemesanan, jarak supplier, dan pelayanan. Kemudian untuk pengolahan data menggunakan TOPSIS dapat diketahui bahwa supplier Surabaya merupakan supplier yang paling potensial. Prioritas alternative selanjutnya berdasarkan rangking secara berturut-turut yaitu, Supplier Semarang, Supplier Solo, dan Supplier Bandung.
\end{abstract}

Kata kunci: Analytical Hierarchy Process; Pemilihan Supplier; TOPSIS

\begin{abstract}
Companies need to evaluate supplier performance to get suppliers to enter according to company criteria. The Problem in PT. Wonorejo Makmur Abadi lacks appropriate criteria and standards to be set in supplier selection so that the company does not evaluate supplier performance. This study aimed to determine the value weights of each criterion used in deciding to choose the best alternative supplier at PT "Wonorejo Makmur Abadi". The criteria used are seven, including Purchase price, quality, payment grace period, delivery accuracy, ability to fulfill the number of orders, supplier distance, and service. To obtain complete data, researchers used methods in the form of interviews and questionnaires. The technique used in data processing in this study is the AHP and TOPSIS methods. Based on data processing using the AHP method, the highest weighted criteria are obtained at the purchase price, followed by successively the quality criteria, payer's grace period, delivery accuracy, ability to fulfill the order quantity, supplier distance, and service. Then for data processing using TOPSIS, it can be seen that Surabaya suppliers are the most potential suppliers. The next alternative priority is based on successive rankings: Semarang Supplier, Solo Supplier, and Bandung Supplier.
\end{abstract}

Keywords: Analytical Hierarchy Process; Supplier Selection; TOPSIS 


\section{PENDAHULUAN}

Proses evaluasi dan pemilihan supplier yang efektif dianggap penting untuk keberhasilan organisasi. Para peneliti sepakat tentang pentingnya supplier dan menyediakan sumber daya untuk kehidupan organisasi. Biaya bahan baku dan bagian-bagian yang terdiri dari produk dianggap sebagai biaya utama di sebagian besar waktu (Asamoah et al., 2012). Ini menggambarkan pentingnya kemitraan yang kuat antara organisasi dan supplier karena berhubungan dengan tingkat biaya yang lebih rendah, kualitas yang lebih baik dan inovasi dalam bisnis, membantu organisasi mencapai keunggulan kompetitif yang berkelanjutan. Untuk selanjutnya, organisasi harus menemukan cara untuk mengevaluasi supplier dan memilih yang terbaik di antara mereka untuk menjadi mitra mereka dalam rantai pasokan (Koufteros et al., 2012).

Pemilihan supplier adalah kegiatan strategis karena supplier akan memasok barangbarang yang kritis atau akan digunakan dalam jangka panjang. keandalan supplier tercermin dalam pengiriman yang murah, berkualitas, tepat waktu dan mampu memberikan layanan yang memuaskan. Tujuan utama dari proses pemilihan supplier adalah untuk mengurangi risiko dan memaksimalkan nilai pembeli. Seleksi supplier adalah bagian dari operasi paling penting di setiap perusahaan. Perhatian besar diberikan pada kualitas input, karena merupakan kondisi yang diperlukan bagi perusahaan untuk menghasilkan produk berkualitas tinggi. Setiap perusahaan menggunakan prosedur sendiri untuk evaluasi dan pemilihan supplier.
PT Wonorejo Makmur Abadi merupakan perusahaan yang bergerak dalam bidang industri manufaktur yang memproduksi tikar. Perusahaan ini berlokasi di Wonorejo, Kecamatan Gondangrejo, Kabupaten Karanganyar, Provinsi Jawa Tengah. Produknya telah berhasil dan sukses dikirim ke berbagai daerah baik di Pulau Jawa maupun luar Pulau Jawa. Pengiriman tikar yang cukup jauh dan memakan waktu cukup lama mengharuskan agar perusahaan memiliki supplier tetap dengan kriteria memiliki kualitas bahan baku yang baik serta ketepatan pengiriman baik dalam segi tepat, waktu, tepat jumlah, dan tepat sasaran. Dalam penelitian ini, permasalahan hanya difokuskan pada pemilihan supplier biji plastik karena merupakan bahan utama dalam pembuatan tikar. Proses bisnis pada PT Wonorejo Makmur Abadi dijelaskan pada gambar 1.

Permasalahan pada pihak supplier di PT Wonorejo Makmur Abadi selama ini adalah belum adanya kriteria dan standar yang tepat untuk ditetapkan dalam pemilihan supplier. Selama ini, tidak ada pemilihan supplier. Siapa yang menawarkan, maka perusahaan akan membelinya sehingga riskan terjadi resiko yang tidak diinginkan perusahaan seperti kualitas bahan yang buruk, lead time yang panjang, pelayanan yang kurang baik, dan lainnya. Ada kalanya supplier mempunyai kriteria yang baik hanya dalam satu sisi seperti kecepatan dalam mengirim sedangkan di sisi lain seperti harga masih belum memenuhi. Perusahaan perlu menyeleksi supplier dengan metode yang tepat agar mendapatkan supplier terbaik yang sesuai dengan kriteria yang dibutuhkan perusahaan.

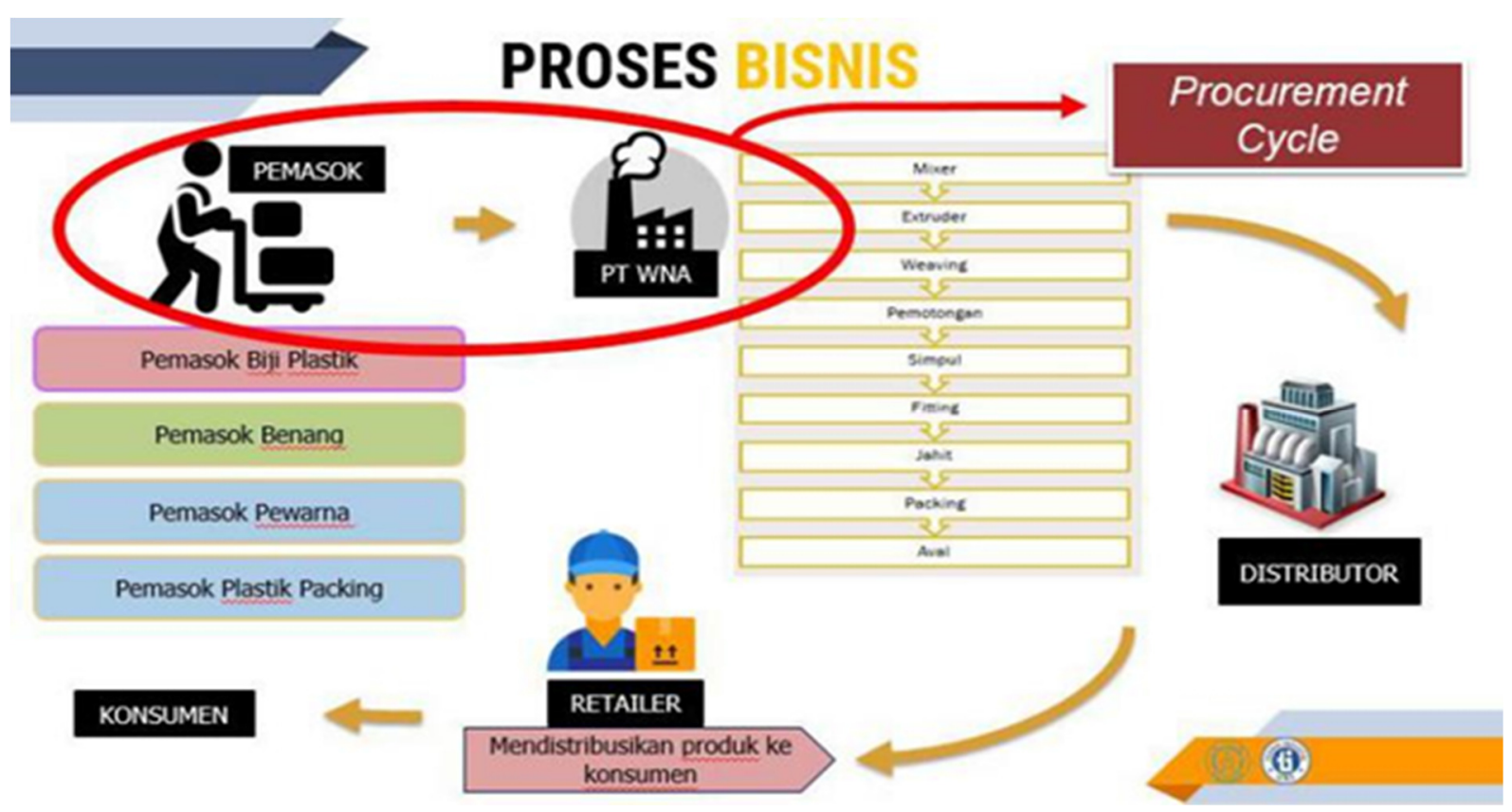

Gambar 1. Proses Bisnis PT. Wonorejo Makmur Abadi 
Integrasi metode AHP dan TOPSIS merupakan salah satu metode yang banyak digunakan dalam penentuan supplier. Metode ini mampu memberikan performansi terbaik dari masing-masing supplier (Taufik et al., 2014) berdasarkan kriteria yang telah ditetapkan (Ngatawi \& Setyaningsih, 2011; Ramayanti \& Ulum, 2017; Siregar, 2019). AHP merupakan alat untuk menentukan bobot prioritas berdasarkan kriteria dan subkriteria yang telah ditetapkan. (Bayazit \& Karpak, 2005). Nilai AHP digunakan sebagai input TOPSIS sebagai penentuan peringkat supplier berdasarkan hasil bobot masing-masing kriteria (Merry et al., 2014). Penelitian ini bertujuan untuk menentukan supplier terbaik pada bahan baku biji plastik serta kriteria yang penting dalam pemilihan supplier tersebut dengan metode Analytical Hierarchy Process (AHP) dan Technique For Others Reference by Similarity to Ideal Solution (TOPSIS). Pada saat ini, perusahaan telah mengidentifikasi ada empat supplier potensial yang nantinya akan dipilih yang terbaik. Dengan memilih supplier yang optimal, perusahaan diharapkan bisa mendapatkan keuntungan baik secara langsung maupun tidak langsung.

\section{METODE PENELITIAN}

Metode penelitian yang digunakan pada penelitian ini meliputi penentuan masalah, pengumpulan data, kemudian menganalisis data mengenai penentuan supplier (Gambar 2). Data yang digunakan yaitu data primer dari wawancara untuk mendapatkan kriteria supplier terbaik. Kemudian, data tersebut dinilai secara kuantitatif oleh pengambil keputusan. Metode penilaiannya menggunakan kuesioner. Asumsi dalam penelitian, antara lain yaitu semua responden mengetahui supplier biji plastik yang bermitra dengan PT Wonorejo Makmur Abadi dan semua responden memahami dan mampu memberikan bobot penilaian terhadap masing-masing supplier melalui kuesioner. Manfaat dari penelitian ini yaitu dapat memilih supplier biji plastik yang terbaik dengan menggunakan metode AHP dan TOPSIS dan dapat mengetahui kualitas dan kinerja dari para supplier yang ada di PT Wonorejo Makmur Abadi.

Data-data dalam penelitian ini didapatkan dari hasil wawancara dan kuesioner. Wawancara dilakukan dengan pihak-pihak yang expert dalam mengambil keputusan perusahaan. Responden merupakan pakar, ahli manajemen, ahli bisnis, dan hasil wawancara sangat representative terhadap pemilihan keputusan dalam pemilihan supplier. Kuesioner tersebut diberikan kepada 3 responden yaitu manajer pembelian, manager logistik, dan manajer produksi. Ketiga responden tersebut sangat mengetahui kondisi perusahaan dan merupakan pengambil keputusan perusahaan. Wawancara dilakukan pada Hari Jum'at, 29 November 2019.

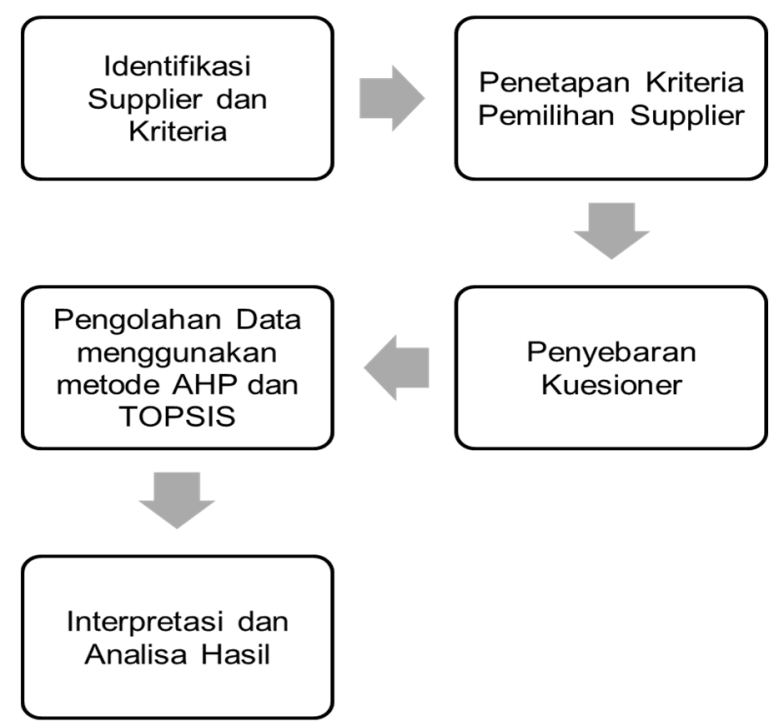

Gambar 2. Tahapan Penelitian

Analytic Hierarchy Process (AHP) dikenal luas karena kekuatannya untuk digunakan sebagai alat yang bermanfaat untuk menyelesaikan masalah pengambilan keputusan yang kompleks (Saaty, 1993). Itu memiliki keuntungan dalam mengevaluasi dan memilih solusi terbaik di antara solusi alternatif, berdasarkan daftar kriteria. Prosedur AHP telah disajikan sebagai langkahlangkah berikut:

Langkah 1: Membangun hierarki keputusan

Langkah 2: Membangun matriks perbandingan bijaksana pasangan

Langkah 3: Membangun matriks keputusan yang dinormalisasi

Langkah 4: Membangun yang tertimbang, dinormalisasi matriks keputusan

Langkah 6: Menghitung nilai Eigen maksimum, $\lambda \max$

Langkah 7: Menghitung indeks konsistensi dan rasio konsistensi

Menurut Tzeng \& Huang (2011) teknik TOPSIS merupakan metode preferensi pesanan berdasarkan kesamaan dengan solusi ideal. Ini dikenal sebagai alat yang berguna untuk membantu dalam pengambilan keputusan. Ide dasar teknik ini adalah memilih alternatif harus memiliki jarak terpendek dari ideal solusi dan jarak terjauh dari jarak negatif. TOPSIS disajikan sebagai berikut:

Langkah 1: Struktur matriks

Langkah 2: Hitung yang dinormalisasi matriks 
Langkah 3: Buat keputusan dinormalisasi tertimbang matriks dengan mengalikan matriks keputusan dinormalisasi dengan bobotnya yang terkait

Langkah 4: Tentukan solusi ideal dan positif solusi ideal negatif

Langkah 5: Hitung ukuran pemisahan

Langkah 6: Hitung kedekatan relatif ke ideal larutan Langkah 7: Hitung skor total

\section{HASIL DAN PEMBAHASAN Metode AHP}

Kriteria yang digunakan dalam penentuan supplier terbaik diperoleh berdasarkan studi literatur dan penelitian terdahulu. Kriteria terdiri atas harga pembelian, kualitas, waktu pembayaran, ketepatan pengiriman, kemampuan pemenuhan terhadap jumlah pemesanan, jarak supplier dengan perusahaan, dan pelayanan. Struktur Hierarki dari pemilihan supplier yang dijelaskan pada gambar 3 .

Menurut para peneliti prioritas kompetitif dari pemilihan kriteria-kriteria mendukung peran strategis manajemen operasi, mendukung kemampuan organisasi untuk menghadapi persaingan, dan memperkuat keunggulan kompetitif. Empat prioritas pertimbangkan kompetitif kriteria yang biasa digunakan dalam dalam pemilihan keputusan sebagai berikut (Hajar, 2016):

1. Kualitas: merupakan prioritas kompetitif yang penting dalam mengelola operasi, di mana ia mewakili tujuan utama untuk setiap manajer. Organisasi mendapatkan manfaat produk berkualitas tinggi dalam meningkatkan nilai tambah untuk produk dari sudut pandang pelanggan, yang pada gilirannya mengarah pada peningkatan profitabilitas dan tingkat efisiensi organisasi, mengurangi biaya yang terkait dengan proses produksi.
2. Biaya: merupakan kebutuhan untuk proses produksi dan layanan. Biaya adalah salah satu faktor penting dalam menentukan kompetitif sebagian besar perusahaan, di mana peningkatan laba dengan mengurangi biaya lebih mudah daripada melalui peningkatan penjualan.

3. Pengiriman: merupakan kemampuan organisasi untuk menyediakan produk dalam waktu tertentu dan sesuai dengan periode penjadwalan tertentu. ada tiga dimensi kompetitif untuk prioritas pengiriman: Kecepatan pengiriman yang berarti kecepatan respons terhadap pesanan pelanggan. Waktu pengiriman atau ketergantungan pengiriman yang berarti kisaran kepatuhan dengan pengiriman produk pada waktu tertentu yang disepakati. Dan kecepatan pengembangan yang berarti kecepatan organisasi untuk mengembangkan, merancang, dan menghasilkan produk baru, di mana ia lebih suka dari organisasi untuk dapat mengembangkan produk sendiri lebih cepat daripada pesaing (Krajewski \& Ritzman, 2005).

4. Fleksibilitas/Service: kemampuan organisasi untuk merespons dan mengadopsi dengan cepat untuk menyiapkan pesanan pasar dan siap dalam jumlah dan kualitas yang dibutuhkan, dan sesuai dengan pesanan pelanggan.

Selain itu, berdasarkan keinginan manajer di PT Wonorejo Makmur Abadi sendiri, kriteria lain yang perlu diperhatikan dalam pemilihan supplier adalah waktu tenggang pembayaran, kemampuan pemenuhan terhadap jumlah pemesanan dan jarak supplier dengan perusahaan. Sehingga dipilih tujuh kriteria yang menjadi dasar dalam pemilihan supplier di perusahaan tersebut. Pembobotan untuk setiap kriteria berdasarkan wawancara terhadap manajer perusahaan.

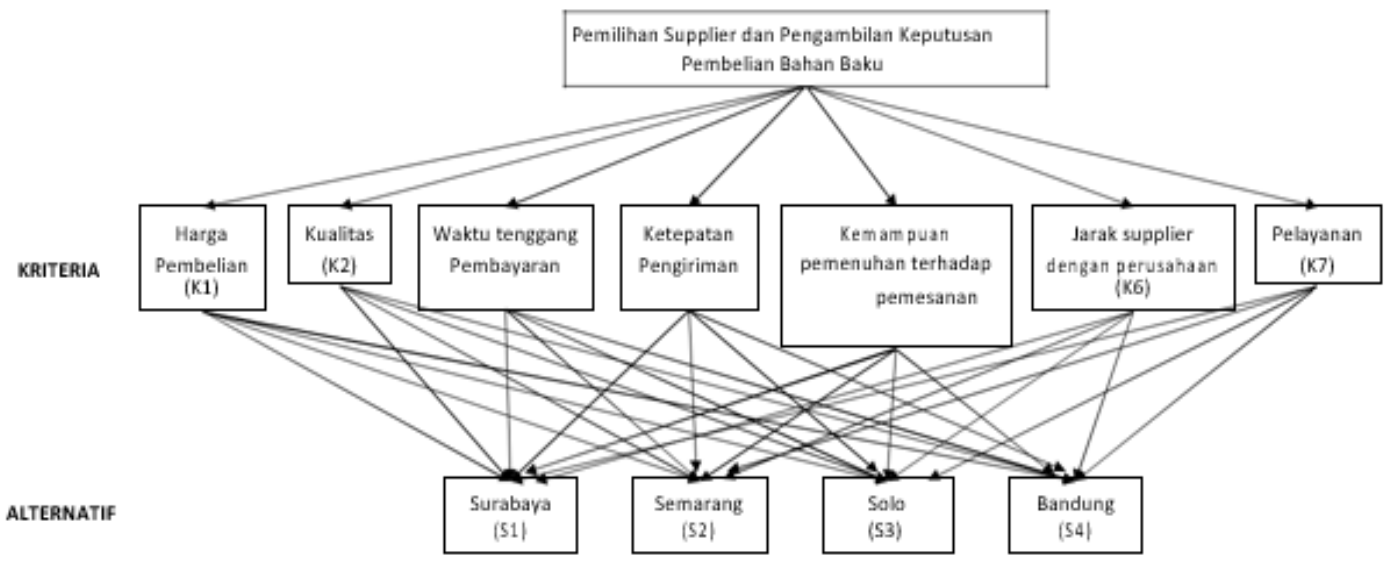

Gambar 3. Struktur Hirarki Pemilihan Kriteria Supplier 
Perbandingan berpasangan (pairwise comparison) dilakukan dengan membandingkan elemen satu dengan elemen lainnya. Angka didapatkan dari hasil kuisioner yang telah diisi responden kemudian diolah dengan matriks metode AHP. WGMC yang merupakan resume hasil dari matriks berpasangan terdapat pada Tabel 1 dan Tabel 2.

Normalisasi didapatkan dari hasil pembagian setiap nilai pada kolom ke-i dan baris ke-j dengan total nilai pada kolom ke-i. Kolom jumlah didapatkan dari hasil penjumlahan tiap baris $\mathrm{j}$, sedangkan vektor bobot didapatkan dari rata-rata nilai normalisasi tiap baris ke-j seperti pada Tabel 3 untuk antar supplier dimana S02 mempunyai nilai vektr terbesar yaitu 0,381 dan Tabel 4 untuk antar kriteria dengan vektor bobot terbesar pada kriteria harga pembelian (K1) dengan nilai 0,213.

Perhitungan Eigen Vector dilakukan dengan mengalikan matriks awal dengan vektor bobot. Berdasarkan perhitungan matriks, didapatkan nilai Eigen Vector pada kriteria supplier S01 sebesar 2,2537, S02 sebesar 1,68963. S03 sebesar 0,7463 dan S04 dengan nilai 0,72323 . Nilai Eigen Vector pada masingmasing kriteria adalah $\mathrm{K} 1$ sebesar $1,552, \mathrm{~K} 2$ adalah 0,793 , K3 dengan nilai 0,862, K4 sebesar 0,488 , K5 sebesar $0,524, K 6$ dengan nilai 0,458 dan $\mathrm{K} 7$ sebesar 0,340 .

Tabel 1. WGMC (Weighted Geometric Mean Complex) antar Supplier pada setiap kriteria

\begin{tabular}{ccccc}
\hline Supplier & S01 & S02 & S03 & S04 \\
\hline S01 & 1,000 & 1,667 & 1,000 & 1,000 \\
S02 & 0,600 & 1,000 & 3,000 & 3,667 \\
S03 & 1,000 & 0,333 & 1,000 & 1,000 \\
S04 & 1,000 & 0,272 & 1,000 & 1,000 \\
\hline
\end{tabular}

Tabel 2. WGMC (Weighted Geometric Mean Complex) Kriteria

\begin{tabular}{cccccccc}
\hline Kriteria & K1 & K2 & K3 & K4 & K5 & K6 & K7 \\
\hline K1 & 1,000 & 1,667 & 2,333 & 3,000 & 5,000 & 2,333 & 3,000 \\
K2 & 0,600 & 1,000 & 1,000 & 2,333 & 1,000 & 2,333 & 1,000 \\
K3 & 0,428 & 1,000 & 1,000 & 3,000 & 1,667 & 1,000 & 3,000 \\
K4 & 0,333 & 0,428 & 0,333 & 1,000 & 1,000 & 1,667 & 1,667 \\
K5 & 0,200 & 1,000 & 0,600 & 1,000 & 1,000 & 1,667 & 1,000 \\
K6 & 0,428 & 0,428 & 1,000 & 0,600 & 0,600 & 1,000 & 1,000 \\
K7 & 0,333 & 0,006 & 0,333 & 0,600 & 1,000 & 1,000 & 1,000 \\
\hline
\end{tabular}

Tabel 3. Normalisasi Matriks Berganda antar Supplier

\begin{tabular}{ccccccc}
\hline Supplier & S01 & S02 & S03 & S04 & Jumlah & Vektor bobot \\
\hline S01 & 0,278 & 0,509 & 0,167 & 0,150 & 1,104 & 0,276 \\
S02 & 0,167 & 0,306 & 0,500 & 0,550 & 1,522 & 0,381 \\
S03 & 0,278 & 0,102 & 0,167 & 0,150 & 0,696 & 0,174 \\
S04 & 0,278 & 0,083 & 0,167 & 0,150 & 0,678 & 0,169 \\
\hline
\end{tabular}

Tabel 4. Normalisasi Matriks Berganda antar Kriteria

\begin{tabular}{cccccccccc}
\hline Kriteria & K1 & K2 & K3 & K4 & K5 & K6 & K7 & Jumlah & $\begin{array}{c}\text { Vector } \\
\text { Bobot }\end{array}$ \\
\hline K1 & 0,301 & 0,301 & 0,354 & 0,260 & 0,444 & 0,212 & 0,257 & 2,129 & 0,213 \\
K2 & 0,181 & 0,181 & 0,152 & 0,202 & 0,089 & 0,212 & 0,086 & 1,102 & 0,110 \\
K3 & 0,129 & 0,181 & 0,152 & 0,260 & 0,148 & 0,091 & 0,257 & 1,217 & 0,122 \\
K4 & 0,100 & 0,077 & 0,051 & 0,087 & 0,089 & 0,152 & 0,143 & 0,698 & 0,070 \\
K5 & 0,060 & 0,181 & 0,091 & 0,087 & 0,089 & 0,152 & 0,086 & 0,745 & 0,074 \\
K6 & 0,129 & 0,077 & 0,152 & 0,052 & 0,053 & 0,091 & 0,086 & 0,640 & 0,064 \\
K7 & 0,100 & 0,001 & 0,051 & 0,052 & 0,089 & 0,091 & 0,086 & 0,469 & 0,047 \\
\hline
\end{tabular}


Langkah selanjutnya yaitu menghitung Consistency Index $(\mathrm{Cl})$ berdasarkan nilai Eigen Value dan Vector Bobot didapatkan hasil perhitungan pada Tabel 5.

Tabel 5. Hasil perhitungan

\begin{tabular}{cccc}
\hline $\boldsymbol{E} \boldsymbol{V}$ & VB & EV/VB & $\boldsymbol{\lambda}$ \\
\hline 1,552 & 0,212 & 7,292 & 7,139 \\
0,793 & 0,110 & 7,199 & \\
0,861 & 0,122 & 7,076 & \\
0,488 & 0,070 & 6,988 & \\
0,524 & 0,074 & 7,033 & \\
0,458 & 0,064 & 7,153 & \\
0,339 & 0,047 & 7,233 & \\
\hline \multicolumn{3}{c}{ Total } & 49,977 \\
\end{tabular}

- Menentukan Consistency Index (Cl)

$$
C I=\frac{(\lambda-n)}{(n-1)}=\frac{(7,1396-7)}{(7-1)}=0,22159
$$

- $\quad$ Menentukan CR

$$
C R=\frac{C I}{R I}=\frac{0,14123}{1,32}=0,106992
$$

Nilai CR pada Supplier sebesar 0.106992 yang berarti bahwa nilai $C R \leq 0,1$ maka penilaian tersebut konsisten.

Penentuan supplier dan kategori terpilih berdasarkan nilai eigen value yang tertinggi. Supplier terpilih adalah supplier 1 yaitu supplier surabaya dengan nilai eigen value tertinggi yaitu sebesar 2,25370. Urutan rangking pemilihan supplier yaitu Surabaya, Semarang, Solo, dan Bandung. Sementara itu, kriteria yang perlu dipertimbangkan dalam menentukan supplier terbaik adalah kriteria pertama yaitu harga pembelian, dengan nilai eigen sebesar 1,552. Selanjutnya adalah waktu pembayaran, kualitas, kemampuan pemenuhan terhadap jumlah pemesanan, ketepatan pengiriman, jarak supplier dengan perusahaan, dan pelayanan.

\section{Metode TOPSIS}

Setelah melakukan penilaian data kualitatif pada kuesioner, selanjutnya adalah melakukan pengolahan dengan menggunakan metode TOPSIS. Kriteria C1 merupakan kriteria harga pembelian, kriteria $\mathrm{C} 2$ merupakan kriteria untuk kualitas, kriteria C3 merupakan kriteria untuk waktu pembayaran, kriteria C4 merupakan kriteria untuk ketepatan pengiriman, kriteria C5 merupakan kriteria untuk kemampuan pemenuhan terhadap jumlah pemesanan, kriteria C6 merupakan kriteria untuk jarak supplier dengan perusahaan, dan kriteria C7 merupakan kriteria untuk pelayanan. Alternatif (A1) merupakan alternatif supplier untuk supplier Semarang, alternatif (A2) merupakan alternatif supplier untuk supplier Solo, alternatif (A3) merupakan alternatif supplier untuk supplier Surabaya dan alternatif (A4) merupakan alternatif supplier untuk supplier Bandung. Langkah awal dalam TOPSIS adalah melakukan normalisasi bobot kriteria (Tabel 6), matriks keputusan (Tabel 7) dan Normalisasi distributive (Tabel 8).

Tabel 6. Normalisasi Bobot Kriteria

\begin{tabular}{lcc}
\hline \multicolumn{1}{c}{ Kriteria } & $\begin{array}{c}\text { Bobot } \\
\text { Kriteria }\end{array}$ & Normalisasi \\
\hline Harga Pembelian & 5 & 00.22 \\
Kualitas & 3 & 00.13 \\
Waktu Pembayaran & 4 & 00.17 \\
$\begin{array}{l}\text { Ketepatan Pengiriman } \\
\text { Kemampuan }\end{array}$ & 3 & 00.13 \\
$\begin{array}{l}\text { Pemenuhan terhadap } \\
\text { jumlah pemesanan }\end{array}$ & 3 & 00.13 \\
$\begin{array}{l}\text { Jarak Supplier dengan } \\
\text { Perusahaan } \\
\text { Pelayanan }\end{array}$ & 3 & 00.13 \\
\hline
\end{tabular}

Tabel 7. Matriks Keputusan (aij)

\begin{tabular}{lccccccc}
\hline Criteria/Alternative & C1 & C2 & C3 & C4 & C5 & C6 & C7 \\
\hline Semarang & 11000 & 4 & 3 & 4 & 4 & 4 & 3 \\
Solo & 11000 & 3 & 4 & 3 & 3 & 4 & 3 \\
Surabaya & 10500 & 5 & 5 & 4 & 4 & 3 & 4 \\
Bandung & 12000 & 3 & 4 & 4 & 3 & 2 & 2 \\
SQRTa^2ij & 19371.37 & 6,56 & 7,55 & 6,40 & 5,83 & 5,39 & 5,39 \\
Total aij & 44500 & 15 & 16 & 15 & 14 & 13 & 12 \\
\hline
\end{tabular}

Tabel 8. Normalisasi Distributif

\begin{tabular}{cccccccc}
\hline Criteria/ Alternative & C1 & C2 & C3 & C4 & C5 & C6 & C7 \\
\hline Semarang & 0,49 & 0,52 & 0,37 & 0,53 & 0,57 & 0,60 & 0,49 \\
Solo & 0,49 & 0,39 & 0,49 & 0,40 & 0,42 & 0,60 & 0,49 \\
Surabaya & 0,47 & 0,65 & 0,62 & 0,53 & 0,57 & 0,45 & 0,65 \\
Bandung & 0,54 & 0,39 & 0,49 & 0,53 & 0,42 & 0,30 & 0,32 \\
\hline
\end{tabular}


Langkah kedua dalam pengolahan data dengan menggunakan metode TOPSIS yaitu menghitung bobot dengan cara:

$$
V=W_{i} \times r_{a i}
$$

$V=\left[\begin{array}{llllll}0,22 & 0,13 & 0,17 & 0,13 & 0,13 & 0,130,09\end{array}\right]$

$\left[\begin{array}{lllllll}0,49 & 0,52 & 0,37 & 0,53 & 0,57 & 0,60 & 0,49 \\ 0,49 & 0,39 & 0,49 & 0,40 & 0,42 & 0,60 & 0,49 \\ 0,47 & 0,65 & 0,62 & 0,53 & 0,57 & 0,45 & 0,65 \\ 0,54 & 0,39 & 0,49 & 0,53 & 0,42 & 0,30 & 0,32\end{array}\right]$

$\left[\begin{array}{lllllll}0,11 & 0,07 & 0,06 & 0,07 & 0,07 & 0,07 & 0,04\end{array}\right]$

$V=\left[\begin{array}{lllllll}0,11 & 0,05 & 0,09 & 0,05 & 0,05 & 0,07 & 0,04 \\ 0,10 & 0,08 & 0,11 & 0,07 & 0,07 & 0,05 & 0,05\end{array}\right.$

$\begin{array}{lllllll}0,10 & 0,08 & 0,11 & 0,07 & 0,07 & 0,05 & 0,05 \\ 0,11 & 0,05 & 0,08 & 0,06 & 0,05 & 0,03 & 0,02\end{array}$

$\left[\begin{array}{lllllll}0,11 & 0,05 & 0,08 & 0,06 & 0,05 & 0,03 & 0,02\end{array}\right]$

Langkah ketiga dalam pengolahan data dengan menggunakan metode TOPSIS yaitu dengan menentukan nilai solusi ideal positif dan solusi ideal negatif dengan cara:

$A^{+}=\left\{v_{i}^{+}, \ldots \ldots, v_{m}^{+}\right\}$

$A^{-}=\left\{v_{i}^{-}, \ldots \ldots, v_{m}^{-}\right\}$

Dimana $v_{i}^{+}=\max _{a}\left(v_{a i}\right)$ jika kriteria $i$ dimaksimalkan dan $v_{i}^{-}=\min n_{a}\left(v_{a i}\right)$ jika kriteria diminimalkan (tabel 9).

$A^{+}=\left[\max v_{a i}, \max v_{a i}, \max v_{a i}, \max v_{a i}\right]$ $[0,27 ; 0,29 ; 0,36 ; 0,29]$

$A^{-}=\left[\min , \min v_{a i}, \min v_{a i}, \min v_{a i}\right]$ $[0,24 ; 0,23 ; 0,18 ; 0,15]$

Tabel 9. Nilai solusi ideal positif dan solusi ideal negatif

\begin{tabular}{cccccccc}
\hline vj+ & 0.12 & 0.08 & 0.11 & 0.07 & 0.07 & 0.08 & 0.06 \\
\hline vj- & 0.10 & 0.05 & 0.06 & 0.05 & 0.06 & 0.04 & 0.03 \\
\hline
\end{tabular}

Langkah keempat dalam pengolahan data dengan menggunakan metode TOPSIS yaitu dengan menghitung jarak masing-masing alternatif dari solusi ideal dengan cara (Tabel 10):

$$
\begin{aligned}
& d_{a}^{+}=\sqrt{\sum i\left(v_{i}^{*}-v_{a i}\right)^{2}}, a=1, \ldots, m \\
& d_{a}^{-}=\sqrt{\sum i\left(v_{i}^{-}-v_{a i}\right)^{2}}, a=1, \ldots, m
\end{aligned}
$$

Tabel 10. Jarak Masing-masing Alternatif Normalisasi Distributif

\begin{tabular}{cc}
\hline da+ & da- \\
\hline 0.05 & 0.05 \\
0.05 & 0.05 \\
0.02 & 0.07 \\
0.07 & 0.03 \\
\hline
\end{tabular}

Langkah kelima menghitung nilai relatif terdekat dengan solusi ideal. Relatif terdekat alternatif aj terhadap A yang disajikan pada Tabel 11. Langkah keenam ialah menentukan urutan preferensi yang disajikan pada Tabel 12.

Tabel 11. Nilai Relatif Normalisasi Distributif

\begin{tabular}{lc}
\hline Alternatif & cli \\
\hline Semarang & 0.51 \\
Solo & 0.48 \\
Surabaya & 0.74 \\
Bandung & 0.32 \\
\hline
\end{tabular}

Tabel 12. Urutan Preferensi dengan Menggunakan Normalisasi Distributif

\begin{tabular}{ccc}
\hline Alternatif & $\begin{array}{c}\text { TOPSIS } \\
\text { Indeks }\end{array}$ & Rank \\
\hline Semarang & 0.51 & 2 \\
Solo & 0.48 & 3 \\
Surabaya & 0.74 & 1 \\
Bandung & 0.32 & 4 \\
\hline
\end{tabular}

Untuk hasil perhitungan normalisasi distributif dengan metode TOPSIS didapatkan hasil supplier yang memiliki indeks tertinggi pada PT Wonorejo Makmur Abadi indeks adalah supplier Surabaya dengan indeks sebesar 0.74 diikuti dengan supplier Semarang dengan indeks sebesar 0.51 , supplier Solo dengan indeks sebesar 0.48 , dan supplier Bandung dengan indeks sebesar 0.32. Hal ini dikarenakan nilai kriteria pemilihan supplier bahan baku biji plastik dari supplier Surabaya mempunyai bobot tertinggi diantara yang lain. Hasil ini menunjukkan bahwa integrasi metode ini mampu memudahkan manajemen dalam mengambil keputusan berdasarkan rangking supplier dari kriteria yang telah ditetapkan (Lukmandono et al., 2019; Muharam et al., 2019; Sundana \& Risdiyanti, 2019).

\section{KESIMPULAN}

Berdasarkan hasil metode AHP dapat diketahui supplier yang mempunyai nilai tertinggi adalah supplier Surabaya. Rangking supplier berikutnya setelah Surabaya adalah Semarang, Solo, lalu Bandung. Kriteria yang paling dipertimbangkan dalam menentukan supplier adalah harga pembelian selanjutnya adalah waktu pembayaran, kualitas, kemampuan pemenuhan terhadap jumlah pemesanan, ketepatan pengiriman, jarak supplier dengan perusahaan, dan pelayanan. Urutan rangking supplier dengan menggunakan metode TOPSIS adalah Surabaya, Semarang, Solo, dan Bandung. Hasil metode AHP dan TOPSIS menghasilkan keputusan yang sama untuk pemilihan supplier terbaik yaitu Supplier Surabaya. Hasil ini dapat digunakan perusahaan dalam pemilihan supplier tetap untuk meningkatkan efisiensi perusahaan mengurangi 
resiko bahan baku yang tidak diinginkan. Penelitian selanjutnya dapat dilakukan dengan menggunakan metode MCDM dengan penambahan dapat diperiksa secara lebih rinci tentang aspek kontinuitas kemampuan supplier untuk kesinambungan pasokan, daya tahan, dan keamanan produk yang ditawarkan.

\section{DAFTAR PUSTAKA}

Asamoah, D., Annan, J., \& Nyarko, S. (2012). AHP Approach for Supplier Evaluation and Selection in a Pharmaceutical Manufacturing Firm in Ghana. International Journal of Business and Management, 7(10), 49-62. http://dspace.knust.edu.gh/handle/1234567 $89 / 11626$

Bayazit, O., \& Karpak, B. (2005). An AHP application in vendor selection. The 8th International Symposium on the Analytic Hierarchy Process, 8-10. http://www.isahp.org/2005Proceedings/Pap ers/KarpakB_Bayazit_VendorSelection.pdf

Hajar, Y. A. A. (2016). Using Analytical Hierarchy Process (AHP) to Build Suppliers' Selection Model. International Journal of Academic Research in Business and Social Sciences, 6(12) 2222-6990. http://hrmars.com/hrmars papers/Using An alytical_Hierarchy_Process_(AHP)_to_Build Suppliers_Selection_Model.pdf

Koufteros, X., Vickery, S. K., \& Dröge, C. (2012). The effects of strategic supplier selection on buyer competitive performance in matched domains: does supplier integration mediate the relationships? Journal of Supply Chain Management, 48(2), 93-115. https://doi.org/https://doi.org/10.1111/j.1745 -493X.2012.03263.X

Krajewski, L. J., \& Ritzman, L. P. (2005). Operations Management: Processes and Value Chains. Pearson Education International/Prentice Hall.

Lukmandono, L., Basuki, M., Hidayat, M. J., \& Setyawan, V. (2019). Pemilihan Supplier Industri Manufaktur Dengan Pendekatan AHP dan TOPSIS. OPSI, 12(2), 83-88. https://doi.org/https://doi.org/10.31315/opsi. v12i2.3146

Merry, L., Ginting, M., \& Marpaung, B. (2014). Pemilihan supplier buah dengan pendekatan metode Analytical Hierarchy Process (AHP) dan TOPSIS: Studi kasus pada perusahaan retail. Jurnal Teknik Dan IImu Komputer, 3(9),

48-58.

http://ejournal.ukrida.ac.id/ojs/index.php/JTI $\mathrm{K} /$ article/view/831

Muharam, H., Cahyadi, U., \& Taptajani, D. S. (2019). Pemilihan Supplier Bahan Baku
Rangining Singkong Dengan Pendekatan Metode Analitycal Hierarchy Process dan Topsis. Jurnal Kalibrasi, 17(2), 10-16. https://jurnal.sttgarut.ac.id/index.php/kalibra si/article/view/672

Ngatawi, N., \& Setyaningsih, I. (2011). Analisis Pemilihan Supplier Menggunakan Metode Analytic Hierarchy Process (AHP). Jurnal IImiah Teknik Industri, 10(1), 7-13. http://journals.ums.ac.id/index.php/jiti/article /view/1243

Ramayanti, G., \& Ulum, H. (2017). Sistem Penentuan Supplier Kawat Las Dengan Metode Analitycal Hierarchy Process (AHP) dan Technique for Order Preference by Similarity to Ideal Solution (TOPSIS). Jurnal Sistem Dan Manajemen Industri, 1(1), 1218.

https://doi.org/https://doi.org/10.30656/jsmi. v1i1.166

Saaty, T. L. (1993). Pengambilan keputusan bagi para pemimpin, proses hirarki analitik untuk pengambilan keputusan dalam situasi yang kompleks. Jakarta: Pustaka binama pressindo.

Siregar, I. (2019). Supplier Selection by Using Analytical Hierarchy Process (AHP) and Techniques for Order Preference Methods with Similarities to Ideal Solutions (TOPSIS). Journal of Physics: Conference Series, 1339(1),

12023. https://doi.org/https://doi.org/10.1088/17426596/1339/1/012023

Sundana, S., \& Risdiyanti, Y. (2019). Analisis Pemilihan Supplier Case A yang Optimal di PT. ABC. JISI: Jurnal Integrasi Sistem Industri, 6(2), 93-106. https://jurnal.umj.ac.id/index.php/jisi/article/v iew/4904

Taufik, R., Sumantri, Y., \& Tantrika, C. F. M. (2014). Penerapan pemilihan supplier bahan baku ready mix berdasarkan integrasi metode AHP dan TOPSIS (Studi kasus pada PT Merak Jaya Beton, Malang). Jurnal Rekayasa Dan Manajemen Sistem Industri, 2(5), 1067-1076. http://jrmsi.studentjournal.ub.ac.id/index.php /jrmsi/article/view/151

Tzeng, G.-H., \& Huang, J.-J. (2011). Multiple attribute decision making: methods and applications. CRC press. 